\title{
MANGROVE VEGETATION HEALTH ASSESSMENT BASED ON REMOTE SENSING INDICES FOR TANJUNG PIAI, MALAY PENINSULAR
}

\author{
SHERIZA MOHD RAZALI ${ }^{1 *}$, AHMAD AINUDDIN NURUDDIN ${ }^{1}$, \\ MARRYANNA LION ${ }^{2}$
}

\begin{abstract}
${ }^{1}$ Institute of Tropical Forestry and Forest Products, Universiti Putra Malaysia, Serdang 43400, Malaysia, e-mail: ainuddin@upm.edu.my

${ }^{2}$ Forest Research Institute of Malaysia, Kepong, 52109, Malaysia, e-mail: marryanna@frim.gov.my

*Corresponding author e-mail: sheriza@upm.edu.my
\end{abstract}

Received: $28^{\text {th }}$ November 2018, Accepted: $15^{\text {th }}$ May 2019

\begin{abstract}
Mangroves critically require conservation activity due to human encroachment and environmental unsustainability. The forests must be conserving through monitoring activities with an application of remote sensing satellites. Recent high-resolution multispectral satellite was used to produce Normalized Difference Vegetation Index (NDVI) and Tasselled Cap transformation (TC) indices mapping for the area. Satellite Pour l'Observation de la Terre (SPOT) SPOT-6 was employed for ground truthing. The area was only a part of mangrove forest area of Tanjung Piai which estimated about 106 ha. Although, the relationship between the spectral indices and dendrometry parameters was weak, we found a very significant between NDVI (mean) and stem density $(y=10.529 x+12.773)$ with $R 2=0.1579$. The sites with NDVI calculated varied from 0.10 to 0.26 (P1 and P2), under the environmental stress due to sand deposition found was regard as unhealthy vegetation areas. Whereas, site P5 with NDVI (mean) 0.67 is due to far distance from risk wave's zone, therefore having young/growing trees with large lush green cover was regard as healthy vegetation area. High greenness indicated in TC means, the bands respond to a combination of high absorption of chlorophyll in the visible bands and the high reflectance of leaf structures in the near-infrared band, which is characteristic of healthy green vegetation. Overall, our study showed our tested WV-2 image combined with ground data provided valuable information of mangrove health assessment for Tanjung Piai, Johor, Malay Peninsula.
\end{abstract}

Keywords: mangrove; Peninsular Malaysia; Tasselled Cap; vegetation indices

\section{INTRODUCTION}

Mangroves are environmentally and economically important for Malaysia. The forests fulfil socio-economic and environmental functions (Hossain \& Nuruddin, 2016), which include the provision of a large variety of wood and non-wood forest products (NWFPs), and coastal protection against the effects of wind, waves, and water currents. Mangrove forests are pristine and offer a high aqua-biodiversity of lands. Mangrove forests are also sensitive 
lands that are vulnerable to climate change and aggressive human activities. Such disturbances have caused mangrove tree depletion from time to time. In tropical forests, particularly in Peninsular Malaysia forests, conversion has become a threatening factor to mangrove forests. Additionally, mangroves support conservation of biological diversity; protection of coral reefs, sea grass beds, and shipping lanes against siltation; and the provision of spawning grounds and nutrients for a variety of fish and shellfish, including many commercial species (Davies et al., 2010). To date, mangroves are proven nursery areas for shrimp, fish, and crustaceans (Heenkenda et al., 2015). Mangrove forests in Peninsular Malaysia can be found, namely, in Tumpat, located in Delta Kelantan; Matang Mangrove Forest Reserve, Perak; Mangrove Forest, Tanjung Tuan in Port Dickson, Negeri Sembilan, and also Sungai Pulai Forest Reserve in the southern part of Peninsular Malaysia. Disturbances affecting mangroves include land conversion of the seaside to valuable economic assets, such as construction of aquaculture projects, which can diminish the mangrove forests. A report from the Food and Agriculture Organization of the United Nations (FAO) indicated that the mangrove areas have decreased from around 16.1 million hectares in 1990 to 15.6 million hectares in 2010. Elsewhere, Africa is facing problems with mangroves involving poor farming practices; conversion of mangroves to cash crop estates; shrimp farming; and increased clearing and tree cutting for fuel wood and charcoal (Drigo et al., 2009).

Inadequate research on assessing mangrove vegetation under stress has contributed to uncertainty in assessing their current role in the global carbon and water cycle and projecting their future change. Since the importance of mangroves is widely known, with the forest consisting of wide and unique varieties of vegetation that can grow despite exposure to wave impacts and water salinity in the harsh coastal environment (Motamedi et al., 2014), protection and conservation of mangrove areas is a critical task and a prerequisite for further research using the most efficient and recent technology available (Crist \& Cicone, 1984). Studies have found the relationship between human activities and environmental impacts are difficult to assess and regulate in coastal and marine environments because the environmental resources are almost always governed by common property resource (CPR) management systems, whereas terrestrial environments are generally managed by the government or private sector (Sherbinin et al., 2007). Therefore, other types of monitoring systems, such as by available, highly efficient temporal and effective technology, should be adapted.

Since the advent of satellite imagery, the application of remote sensing technology for mangrove conservation is continuing. Spectral information from different satellites provides various information. Remote sensing technology has been integrated in assessing the vulnerability of wetlands and mangroves, especially the utilization of the photochemical reflectance index (PRI) for characterizing plant stress because it can exhibit a strong response to salinity exposure. Satellite technology is suitable for this kind of forest because satellite imagery can provide spectral information on chlorophyll content which, furthermore, can assess vegetation stress. To date, various mathematical combinations of spectral channels in satellite images have been used as sensitive indicators of the present condition and vigour of green vegetation. Hence, many studies demonstrated the usefulness of the indices, a matter that has been discussed comprehensively in (Smith et al., 2014). Mangroves have a certain phenology, such as replacing old leaves with new leaf growth, and they also loosen leaves at a high rate. This can be an indicator that remote sensing can sense the gap during replacement and new growth of leaves.

Researchers continuingly study vegetation stress with the Thematic Mapper (TM)/Enhanced Thematic Mapper (ETM) for the Landsat satellite and the Satellite Pour 
Razali Sh. M., Nuruddin A. A., Lion M.: Mangrove Vegetation Health Assessment Based on Remote Sensing Indices for Tanjung Piai, Malay Peninsular

l'Observation de la Terre (SPOT) satellite, which are among those tested for land use change studies in China (Zhang \& Zhang, 2007). Beyond land use change studies, scientists investigated forests by applying mathematical equations to the spectral bands. A recent study by Schultz et al. (2016) performed various vegetation indices from Landsat data for forest monitoring in tropical forest regions of Brazil, Ethiopia, and Vietnam. In that study, multiple indices were used with the inclusion of the Enhanced Vegetation Index (EVI) and Normalized Difference Vegetation Index (NDVI). There was mention that even more complex mathematical routines are not suitable for mangrove monitoring because of problems with the mangrove phenology stages, which routines can be combined with other indices. Therefore, more studies are required, as suggested by (Kamal et al., 2016).

NDVI is an index based on visible and near-infrared wavelength that was originally introduced by (Rouse et al., 1974). The vegetation index of NDVI, for example, is sensitive to chlorophyll and photosynthetic vegetation (Slik \& Eichhorn, 2003) and, therefore, useful for detecting biomass reduction in tropical forests because of abiotic stress. The index has been tested in forest biomes, including deciduous and evergreen broadleaf, tropical rainforest, herbaceous savannah, and in the succession of crops (Hmimina et al., 2013). Additionally, studies that applied indices for mangrove include (Heenkenda et al., 2016; Kongwongjan et al., 2012; Kovacs et al., 2005), whereas Tasselled Cap transformation is index producing three data structure axes defining the vegetation information content: brightness - a weighted sum of all bands, as determined by the phonological variation in soil reflectance; greenness, which is orthogonal to brightness and measures the contrast between the near-infrared and visible bands; and wetness, which relates to canopy and soil moisture. In a comprehensive statement (Crist \& Cicone, 1984) defined TC as an orientation data plane such that the two features which define it are directly related to physical scene characteristics. Other potential indices include the Soil-Adjusted Vegetation Index (SAVI), which has been applied by (Luo et al., 2010), and the Advanced Vegetation Index (AVI) (Gobron et al., 2000), which was applied elsewhere.

The objective of this study was to employ vegetation indices of NDVI and TC transformation by employing WV2 imagery for assessing a mangrove health area for conservation of the Peninsular Malaysia mangrove forest. This kind of study can be applied for forestry department programs as a conservation mechanism.

\section{METHODOLOGY}

\section{Study Area}

This section is offered to provide some information on the background of the study site. Tanjung Piai serves difference of $40 \%$ in biodiversity aspects from other mangroves sites namely, Pulau Kukup which is located proximity to one and another. The forest structure of the two different types of mangrove forests indicated some similarities in terms of family and species dominance, species diversity and productivity. Both Pulau Kukup and Tanjung Piai were a Bruguiera-Rhizophora mangrove forest type. Both sites had intermediate level of tree species diversity and aboveground biomass (Juliana, 2012). Again, the Tanjung Piai are among richer with natural resources with other areas namely Sungai Pulai Forest Reserve and Pulau Kukup demonstrated in a study of (Yaakup et al., 2006). Tanjung Piai is also importance for natural habitats for shellfishes, residential and migratory water birds and also act as important cockle breeding grounds which also found in the mangrove areas of Kuala Gula, Kuala Merbok, Kuala Selangor, and Pontian. This is because all the area bestowed with 
extensive areas of mudflats as well as other areas of Malaysia's coast facing Straits of Malacca (Amir et al., 2015).

In terms of economic importance, Tanjung Piai was among contribution to sustainability of rural tourism for Malaysia. According to a study conducted by (Amir et al., 2015), they mentioned that Malaysia's tourism industry collected in a Gross National Income (GNI) of RM47.2bil in 2012 and ranked as the second largest foreign exchange earner after manufactured goods and the seventh largest contributor to the Malaysian economy, after referred to other study reported in Malaysia's trusted newspaper.

For social aspects, villagers use the mangrove forests for fishing and some of them have extracted forest resources, for example for coal, and from rivers, such as fishing crabs and shrimps. The study area map is shown in Figure 1. Mangroves surrounding the mainland area experienced land conversion. For example, historical Landsat images in 1989 to 2014 at Tanjung Piai estuarine systems showed land cover had changed dominantly by oil palms, rubber, urban areas. This study found that oil palm plantations increased in 2005 onwards, but, oppositely, rubber showed a drastic decrease of about $96 \%$ (Kanniah et al., 2015).

Fig. 1: Peninsular Malaysia shown the study area with 7, 5, 3 band combination for natural colour derivation.

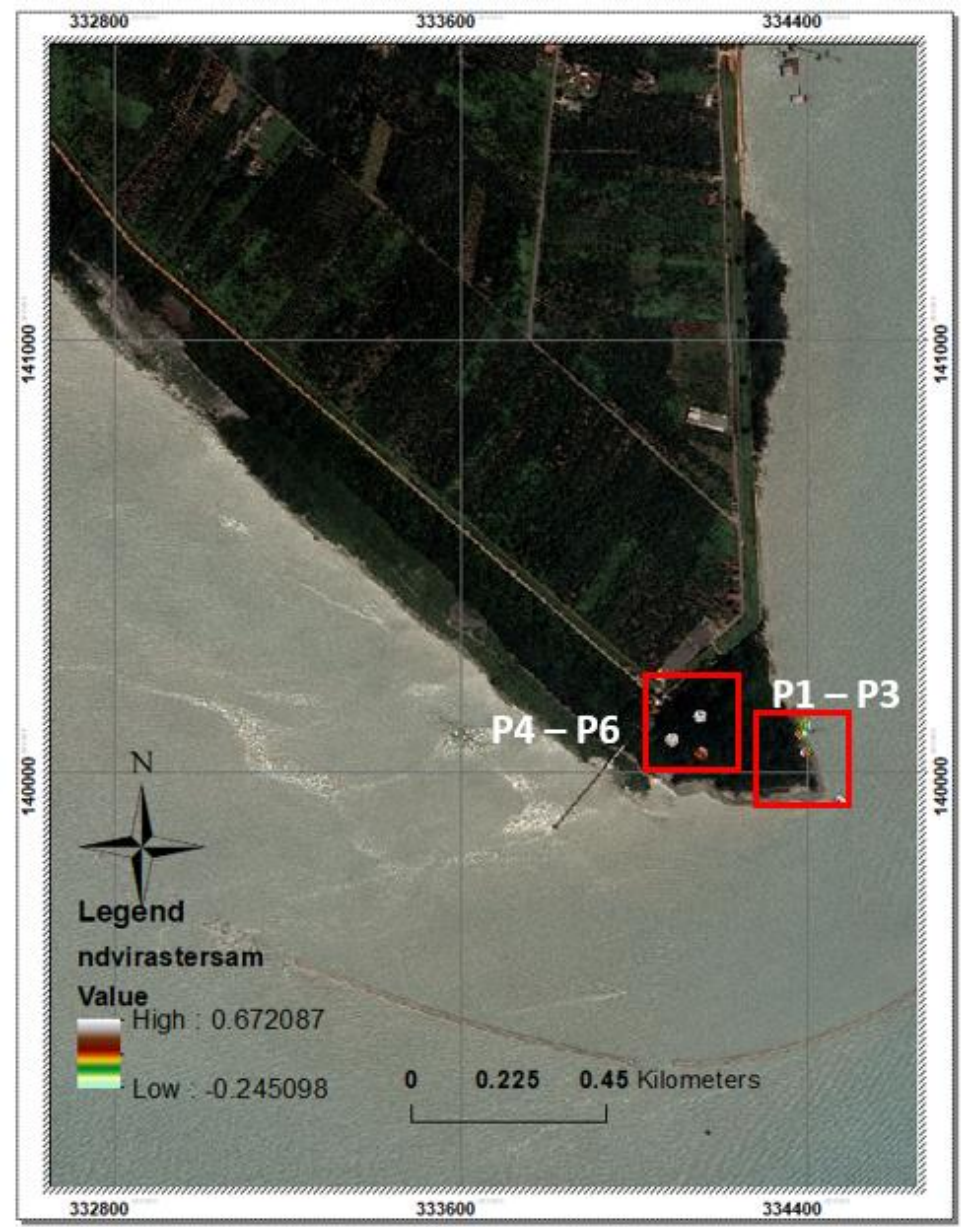


Razali Sh. M., Nuruddin A. A., Lion M.: Mangrove Vegetation Health Assessment Based on Remote Sensing Indices for Tanjung Piai, Malay Peninsular

The pristine land is in Johor National Park's managed piece of land which was registered as The Ramsar Convention on Wetlands of International Importance, RAMSAR site (no. 1289). The area supports many threatened and vulnerable wetland-dependent species, such as the Pig-tailed Macaque and Long-tailed Macaque, birds like the Mangrove Pitta, Mangrove Blue Flycatcher, Mangrove Whistler, and the globally vulnerable Lesser Adjutant which may be observed in the vicinity of the Johor Parks site (RAMSAR, 2003).

\section{Ground data for tree structure sampling}

The fieldwork in Tanjung Piai was conducted in September 2016. The location was pre-visited for geolocation of sampling points. Sampling was conducted to estimate stem density (number of stems $/ 0.01 \mathrm{ha}$ ) and basal area $\left(\mathrm{m}^{2} / 0.01 \mathrm{ha}\right.$ ) as parameters. In this study, a minimum distance of $10 \mathrm{~m} \times 10 \mathrm{~m}$ was chosen to developed sampling plots according to a study by Shah, Mustafa Kamal, Rosli, Hakeem, \& Hoque (2016). The measurement included diameter at breast height (DBH), seedling counting, rubbish observation and the distance $(\mathrm{m})$ between the plots and the walkway and to the sea. The study consisted of six (6) sampling points, which made it a total area of the sampling plots or the study area was $6 \times 100$ $\mathrm{m}^{2}$ or $600 \mathrm{~m}^{2}$ which this procedure allows an understanding of the mean stem diameter of each mangrove species and their relative importance in structuring the mangrove at Tanjung Piai. At each plot, the central coordinates were obtained from GPS and those features were photographed. All these findings (ground inventory) were used to develop a final health vegetation assessment map for Tanjung Piai.

As found in (Lewis et al., 2015), important forest structures attributed to characterizing mangrove health include biomass, basal area, canopy height, frequency, density, dominance, importance value, and the resulting calculated Complexity Index (CI).

\section{Satellite Data and analysis}

Satellite images employed for the study was a WV-2 with a 2.0-m multispectral resolution bands purchased from local vendor which is Dig Dat Company, located in Ampang, Kuala Lumpur, Malaysia. The image dated 15 June 2015 was chosen because the scene showed minimal cloud cover and the location clipped for the study area showed no presence of cloud cover. A study by Kamal et al. (2016) utilized the image for assessment of the leaf area index for mangrove areas in Indonesia. The mangrove area that is located at the seaside makes researching mangrove areas more convenient with respect to handling remote sensing data compared with lowland areas. This is because lowland tropical forests consist of multiple layers, multiple species of forest trees, and a rich forest floor making visualizing forest images in remote sensing more difficult. The application of satellite remote sensing has been emphasized by (Heenkenda et al., 2016) in a study for extracting biophysical variables for the Northern Territory of Australia.

We employed SPOT-6 with $1.5 \mathrm{~m}$ resolution for the ground truthing procedure. In this study, a cloud detection procedure was conducted based on a comparison with Google Earth images of the study area. Mangrove habitat samples with a spectral health index were ground checked on 15 November 2016. In this activity, the ground thruthing points can be referred to Figure 1 and Table 2 for complete locality.

In this study, a cloud detection procedure was conducted based on a comparison with Google Maps imagery of the study area focusing on the area of interest (AOI). Based on the satimagingcorp.com web page, WV-2 is a new satellite after WV-1 which the image have one (1) high-resolution panchromatic band and four (4) new bands (red-edge, coastal, yellow and near infrared-2, and four (4) standard bands consisted of red, green, blue, and near-infrared-1 bands as showed in Table 1. All bands having specific spectral range, for 
example for the new bands: coastal bands with spectral range of 400 to $450 \mathrm{~nm}$ which is a shorter wave blue called coastal blue. Yellow bands have wavelengths of 585 to $625 \mathrm{~nm}$ is a band straddling red edge located at 630 to $690 \mathrm{~nm}$. Finally, a new band of near-infrared-2 slightly overlapped near-infrared 1 and is less than $1110 \mathrm{~nm}$ (Yarbrough et al., 2014).

Table 1: Details specification for WV-2 satellite employed for the index

\begin{tabular}{cccc}
\hline Bands number & Spectral range $(\mathbf{n m})$ & Bands number & Spectral range (nm) \\
\hline B1-Coastal (new) & $400-450$ & B5-Red & $630-690$ \\
B2-Blue & $450-510$ & B6-Red Edge & $705-745$ \\
B3-Green & $510-580$ & B7-Near-Infrared-1 & $770-895$ \\
B4-Yellow (new) & $585-625$ & B8-Near-Infrared-2 & $860-1040$ \\
\hline
\end{tabular}

Table 2: Details of ground verification coordinate

\begin{tabular}{cc}
\hline & Coordinate (x,y) \\
Point & RSO \\
\hline 1 & 612600,139950 \\
2 & 610800,141700 \\
& \\
\hline 3 & 612000,140500 \\
4 & 611700,140800 \\
& \\
\hline 5 & 610500,142300 \\
6 & 612900,140200 \\
\hline 7 & 611100,141700 \\
\hline
\end{tabular}

\section{Normalized Difference Vegetation Index (NDVI)}

NDVI is an index based on visible and near-infrared wavelengths (Rouse et al., 1974). The index has been tested in forest biomes, including deciduous and evergreen broadleaf, tropical rain forest, herbaceous savannah, and also the succession of crops (Hmimina et al., 2013), whereas TC transformation has developed the index by producing three data structure axes defining the vegetation information content: brightness - a weighted sum of all bands, as determined by the phonological variation in soil reflectance; greenness, which is orthogonal to the brightness and measures the contrast between the near-infrared and visible bands; and 
Razali Sh. M., Nuruddin A. A., Lion M.: Mangrove Vegetation Health Assessment Based on Remote Sensing Indices for Tanjung Piai, Malay Peninsular

wetness, which relates to the canopy and soil moisture (Crist \& Cicone, 1984). The objective of this study was to employ NDVI for mangrove health assessing for mangrove areas. The indices have a native scaling of -1 to +1 . See Table 3 for description bands utilised for the calculation.

Table 3: Spectral reflectance indices and WV-2 bands utilized the study

\begin{tabular}{ccc}
\hline Index & Formulation & Source \\
\hline NDVI & (B5 Red - B7 Near-IR1) / (B5 Red + B7 Near-IR1) & {$[12]$} \\
TC & TC Coefficient & {$[25]$} \\
\hline
\end{tabular}

\section{Tasselled Cap Transformation}

Remote sensing technology with advanced of spectral properties combine the reflectance measurements from different portions of the electromagnetic spectrum to provide information about vegetation coverage on the ground. Based on mathematical formulae, the spectral bands were developed for a proper analysis of land features. Vegetation has high reflectance in NIR, but lower in the blue and the red regions of the spectrum due to its absorption by chlorophyll for photosynthesis. Certain vegetation indices can be developed to distinguished stress vegetation among healthy vegetation. In tropical forests, the Tasselled Cap transformation index can be referred to (Kauth \& Thomas, 1976) with the concept of a 'triangular cap-shaped region with a tassel' that can be separated into a 'plane of vegetation' and a 'plane of soil' after comparison with brightness and greenness; and brightness and wetness. In this study, mangrove samples were collected, and tested TC index based on ENVI software.

The index transformed image into Brightness, Greenness, Wetness, Fourth, Fifth and Sixth different equivalent features derived from the image. Each of the characteristics has special applications that have been proven by many studies: brightness for soil, greenness for vegetation, and wetness for the interrelationship of soil and canopy moisture. This study applied Kauth-Thomas (K-T) transform coefficients for the reflectance data of the WV-2 sensor (Yarbrough et al., 2014).

\section{RESULTS}

\section{Mangroves structural attributes}

The results can be referred in Table 4. The results showed that a part of tree density at Tanjung Piai varied between 10 and 24 stems/0.01 ha (sites P4 and P5), while basal area varied from 0.021 to $0.065 \mathrm{~m}^{2} / 0.01$ ha (sites P3 and P1). Other sites, which are site P1 and P2 represent their mature nature with density 15 stems/0.01 ha); basal area 0.049 and 0.065 $\mathrm{m}^{2} / 0.01 \mathrm{ha}$ ) which have relatively low stem densities and high basal areas. Those sites are located 0 to less than $10 \mathrm{~m}$ from bay-mangrove periphery, which they were surrounded with sand pack, rope and plastics, represented mature tree with high risk from sea area (Table 5). Higher density area can be found at sites P3, P5 and P6 is due to its location of more than $10 \mathrm{~m}$ from mangrove periphery bay and this area can represented a young and lush green mangrove forest. The distance indicated heavy outside materials namely, sand pack can't get through particularly to the P5 and P6 sites, therefore protect from sea risen and erosion risks. Site P1 and P2 at the bay-mangrove periphery the most southernmost part of Peninsular 
Malaysia, and it is the most southern section in the Asian mainland, submitted to high-impact current/waves and sand deposition, causing the death and incline of several mature trees.

Table 4: Mangrove structural parameters from sampling

\begin{tabular}{lcccccc}
\hline & \multicolumn{7}{c}{ Site } \\
\hline & P1 & P2 & P3 & P4 & P5 & P6 \\
\hline $\begin{array}{l}\text { Total tree density } \\
\text { (stems/0.01 ha) }\end{array}$ & 15 & 15 & 20 & 10 & 24 & 17 \\
\hline $\begin{array}{l}\text { Total basal area } \\
(\mathrm{m} 2 / 0.01 \text { ha) }\end{array}$ & 0.065 & 0.049 & 0.021 & 0.043 & 0.037 & 0.052 \\
\hline Mean NDVI & 0.10 & 0.26 & 0.38 & 0.44 & 0.57 & 0.57 \\
\hline
\end{tabular}

Table 5: Mangrove of others parameters observed from sampling

\begin{tabular}{|c|c|c|c|c|c|c|c|}
\hline \multirow[t]{2}{*}{ Site } & \multirow[t]{2}{*}{ Rubbish } & \multirow{2}{*}{$\begin{array}{r}\text { Death } \\
\text { Tree }\end{array}$} & \multirow[t]{2}{*}{ Live } & \multirow[t]{2}{*}{ Incline } & \multirow[t]{2}{*}{ Soil } & \multicolumn{2}{|c|}{ Distance } \\
\hline & & & & & & $\begin{array}{c}\text { From } \\
\text { walkway } \\
\text { (meter) }\end{array}$ & $\begin{array}{c}\text { From the } \\
\text { bay-mangrove } \\
\text { periphery(meter) }\end{array}$ \\
\hline $\begin{array}{c}\text { Plot } \\
1\end{array}$ & $\begin{array}{l}\text { Sand pack, rope } \\
\text { and rubbish } \\
\text { plastic }\end{array}$ & 0 & 97 & 2 & $\begin{array}{l}\text { Sandy } \\
\text { eroded }\end{array}$ & $\begin{array}{l}\text { Less than } \\
10 \mathrm{~m}\end{array}$ & $0 \mathrm{~m}$ \\
\hline $\begin{array}{c}\text { Plot } \\
2\end{array}$ & $\begin{array}{l}\text { Sand pack, rope } \\
\text { and rubbish } \\
\text { plastic and ball }\end{array}$ & 3 & 70 & 0 & $\begin{array}{l}\text { Sandy } \\
\text { eroded }\end{array}$ & $\begin{array}{l}\text { More than } \\
10 \mathrm{~m}\end{array}$ & Less than $10 \mathrm{~m}$ \\
\hline $\begin{array}{c}\text { Plot } \\
3\end{array}$ & $\begin{array}{l}\text { Plastic, wood, } \\
\text { net, bottles, } \\
\text { plastic } \\
\text { containers }\end{array}$ & 4 & 33 & 0 & Sandy & $\begin{array}{l}\text { More than } \\
10 \mathrm{~m}\end{array}$ & More than $10 \mathrm{~m}$ \\
\hline $\begin{array}{c}\text { Plot } \\
4\end{array}$ & Food plastic & 4 & 33 & 0 & Sandy & $\begin{array}{l}\text { More than } \\
10 \mathrm{~m}\end{array}$ & More than $10 \mathrm{~m}$ \\
\hline $\begin{array}{c}\text { Plot } \\
5\end{array}$ & $\begin{array}{c}\text { Glass and } \\
\text { plastics bottle }\end{array}$ & 3 & $\begin{array}{l}\text { More } \\
\text { than } \\
200\end{array}$ & 0 & $\begin{array}{l}\text { No soil } \\
\text { erosion }\end{array}$ & $0 \mathrm{~m}$ & More than $10 \mathrm{~m}$ \\
\hline $\begin{array}{c}\text { Plot } \\
6\end{array}$ & $\begin{array}{l}\text { Glass bottles } \\
\text { and }\end{array}$ & 9 & 35 & 0 & $\begin{array}{c}\text { No } \\
\text { erosion }\end{array}$ & $0 \mathrm{~m}$ & More than $10 \mathrm{~m}$ \\
\hline
\end{tabular}

\section{NDVI}

Whereas NDVI data calculated varied from 0.10 to 0.26 (site P1 and P2), under the environmental stress due to sand deposition found by sand pack that caused poor tidal inundation indicated unhealthy vegetation. Meanwhile, Figure 2 showed destruction caused by Iskandar Regional Development Authority (IRDA) development projects. 
Razali Sh. M., Nuruddin A. A., Lion M.: Mangrove Vegetation Health Assessment Based on Remote Sensing Indices for Tanjung Piai, Malay Peninsular

Fig. 2: (a) Fallen trees, as cited in Barau (2017) as a result of Iskandar Regional Development Authority (IRDA) project, and (b) rubbish stuck between trees also found in the study area.

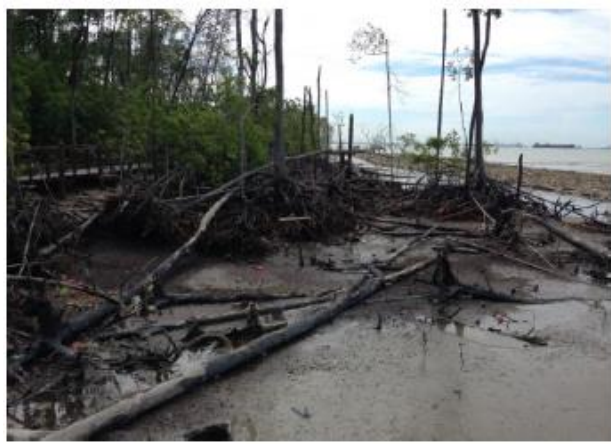

(a)

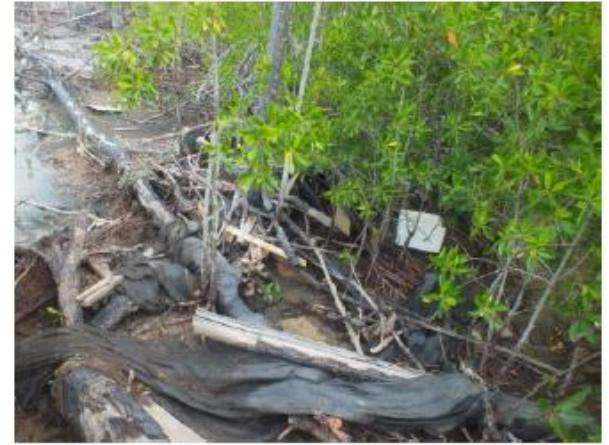

(b)

\section{TC}

In general, TC is important variable as NDVI index to assess nature of the tree. Greenness-wetness space has the same effects on the vegetation and is slightly better than the brightness space in terms of differentiation among wet soils and the green of vegetation.

Fig. 3: TC overlaid with TC band combination (Greenness, Brightness and Wetness) on each transformed spectrum.

\section{(a) Greeness}

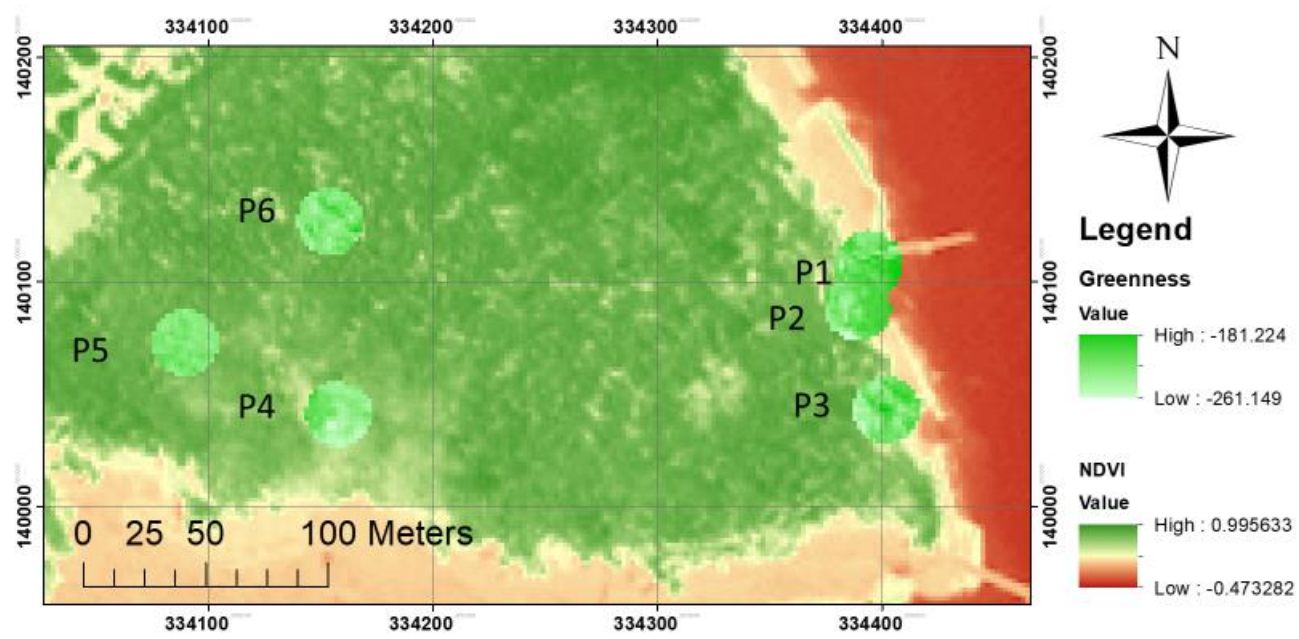




\section{(b) Brightness}

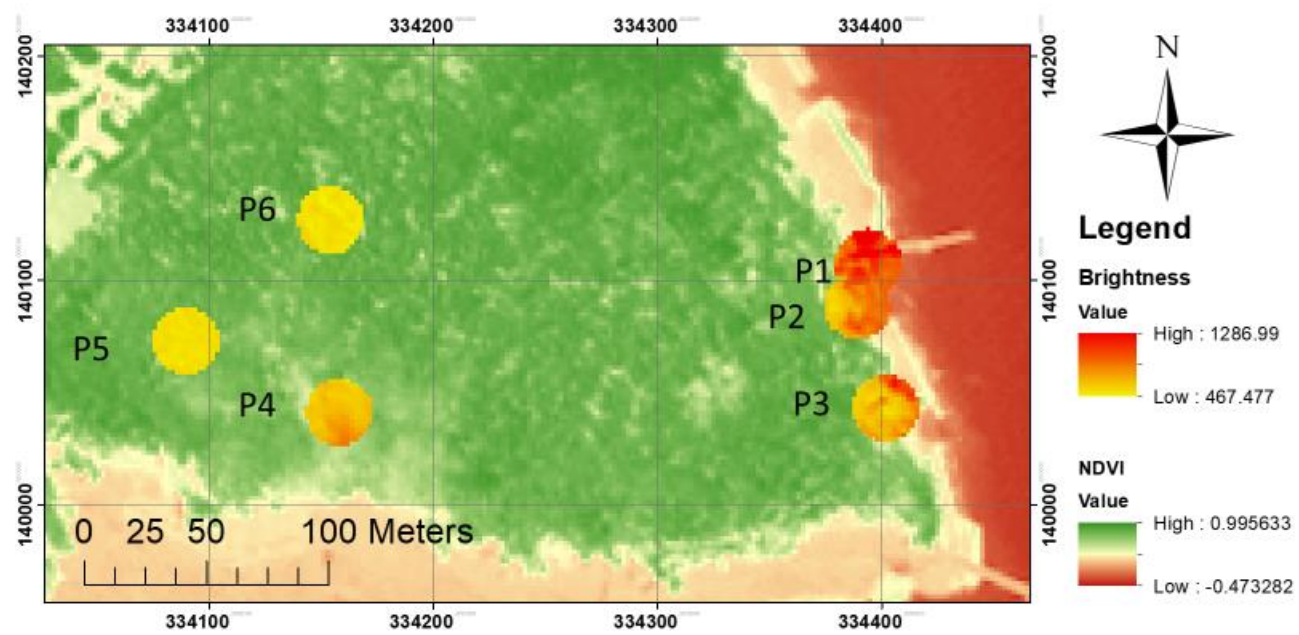

(c) Wetness

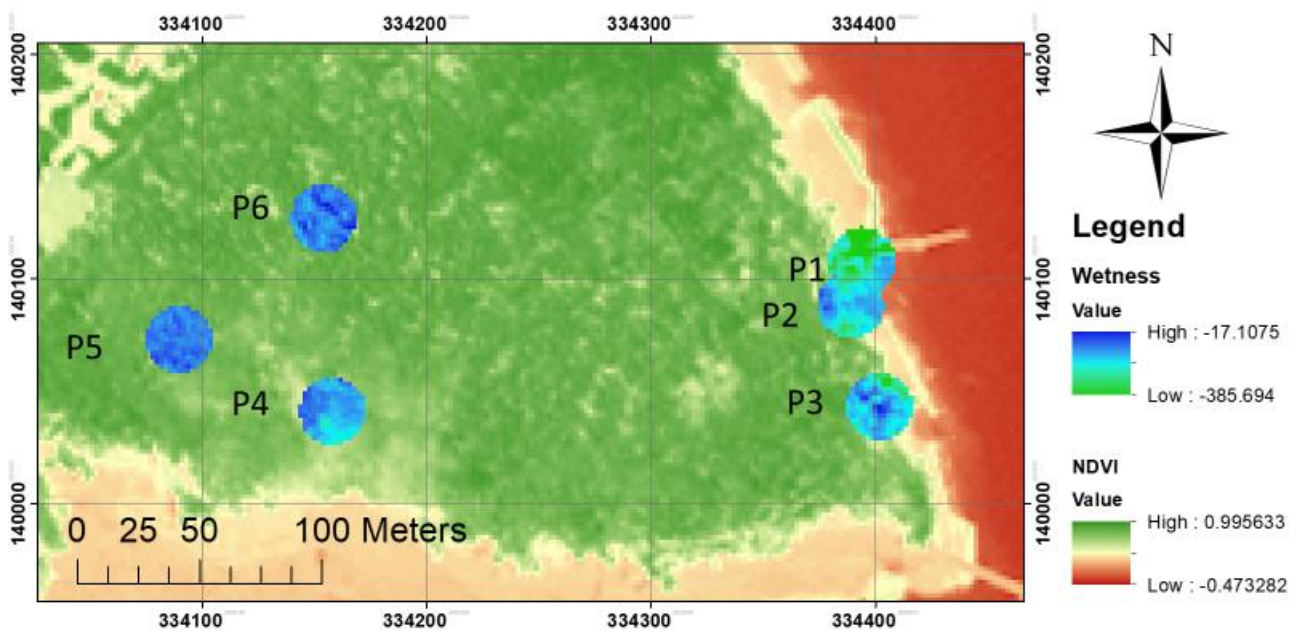

Which high greenness indicated in TC means, the bands respond to a combination of high absorption of chlorophyll in the visible bands and the high reflectance of leaf structures in the near-infrared band, which is characteristic of healthy green vegetation (Yang et al., 2015). Greenness-wetness space has the same effects on the vegetation and is slightly better than the brightness space in terms of differentiation among wet soils and the green of vegetation. TC brightness showed brighter at sites P1 and P2 and relatively much darker at site P5 and P6. As mentioned earlier, among others site P1, P2 and P3 showed less green therefore followed by 
Razali Sh. M., Nuruddin A. A., Lion M.: Mangrove Vegetation Health Assessment Based on Remote Sensing Indices for Tanjung Piai, Malay Peninsular

more wetness captured in the TC image at these sites, indicating trees in this site were in the water due to continuously erosion happen in that area.

\section{The NDVI and its relationship with dendrometry parameters}

Figure 4 shows the NDVI regression results for NDVI (mean) and mangrove density (stems/0.01 ha) and NDVI (mean) and mangrove basal area. The results suggested that the relationship, although relatively weak, but was particularly significant and meaningful between NDVI and mangrove density $(\mathrm{R} 2=0.1579)$.

Fig. 4: Illustration of simple linear regression between (a) mean NDVI and density and (b) mean NDVI and basal area

(a)

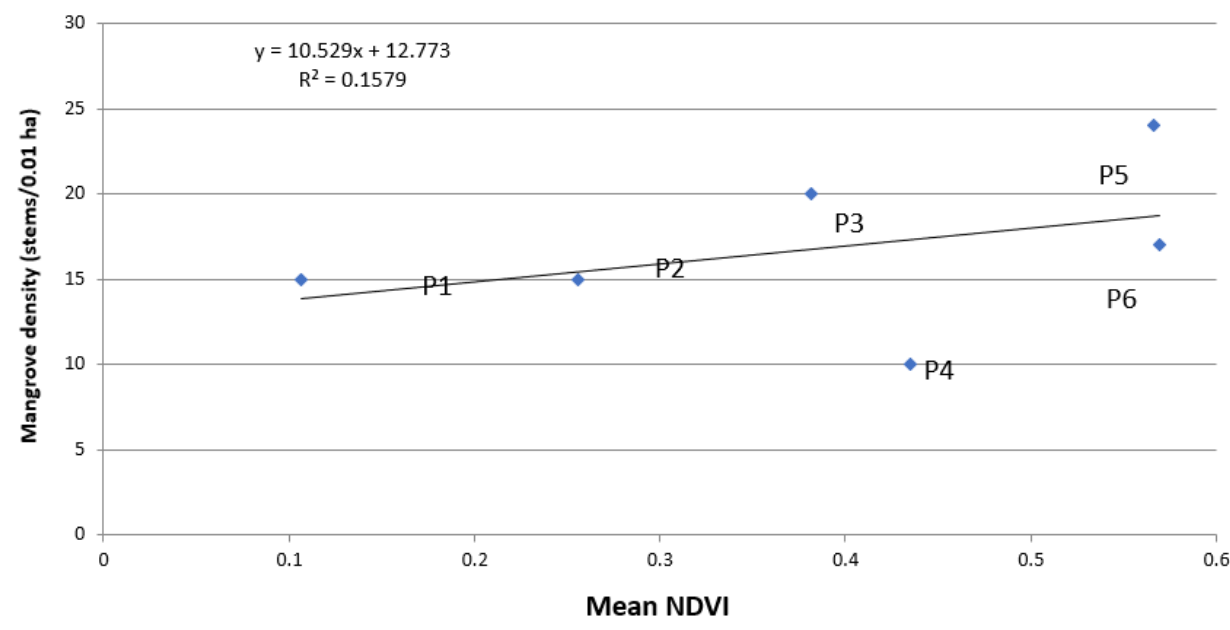

(b)

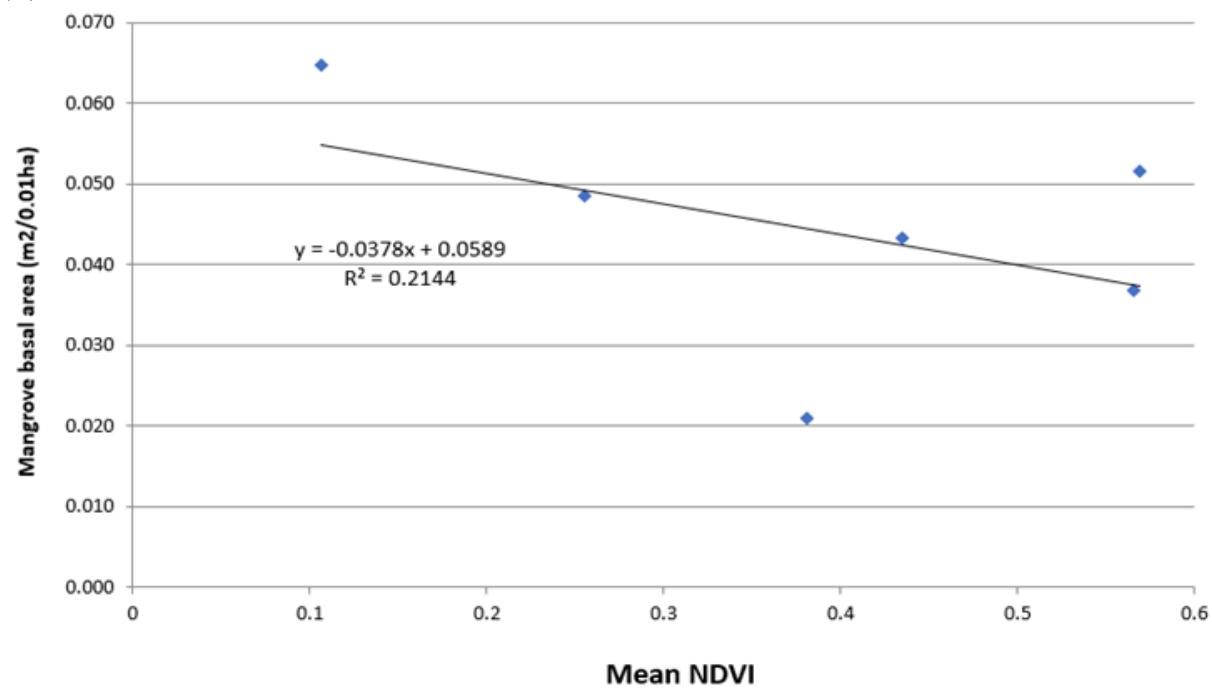




\section{DISCUSSION}

Overall, the study suggests sites can be delineated into two area which is unhealthy and healthy vegetation due to environmental stress. Vegetation can reflect greater NDVI at healthy vegetation sites, in opposite reflected weaker NDVI at unhealthy sites. Study showed healthy vegetation has a higher NDVI value than unhealthy vegetation (Zhang et al., 2005). This indication can also help Johor National Park maintain conservation programs which, at the same time, supports high value mangrove species protection. In fact, high value forests can apply this finding for assisting them to include mangroves as high value forests. The final map can be implemented as a health indicator area for the Forestry Department of Peninsular Malaysia (FDPM) conservation index, for mangrove areas of Tanjung Piai.

TC showed similar results with NDVI, which showed highly greenness transformation of spectral at healthy sites whereas more brightness features at unhealthy sites. Sites trees that standing apart making greenness colour shown from TC much lighter than the healthy vegetation area. This is because mangrove forests usually appear in abundance and have high similarity within one composition if no interference by other factors occurs, such as different logging cycles, disease, or different tree mortality rates that could be caused by strikes, waves, and so on. In addition, greenness was caused by higher density of the sites filling gaps (created in unhealthy vegetation sites) between tress and lowered reflectance value in the area, showed by P5 (stem density: 24; basal area: 0.037). Mangroves always appeared as other plants, which define them as a "community of trees, shrubs, palms or ground ferns, generally exceeding more than half a meter in height, and which normally grows above mean sea level in the intertidal zones of marine coastal environments, or estuarine margins" (Juliana et al., 2014). The spectral index of NDVI and TC has combined the results of the biomass status, the brightness of the soil, the greenness of the vegetation, and the wetness of the water (Crist \& Cicone, 1984; Huang et al., 2002).

The unhealthy vegetation area appeared very near to the sea or bay-mangrove periphery. Therefore, the tree is unsuccessful at overstocking because of the greater tendency for developing gaps, particularly during high sea waves. Due to this, it is susceptible to diseases, poor health, and pests. In general, P1 and P2 has showed its ability for recovering its overall forest health to its natural state with new young seedling emerged (P1:97 and P2: 70) (Table 4). Other sampling points were not able to establish because of inaccessibility to the area, since the area is prohibited for access without research permission from the Department of Irrigation and Drainage. The objectives of the band combinations in TC were to further interpret and extract information from WV-2 data for mangrove vegetation health classification. This is because visual inspection for forest cover is very important because the signature of mangrove forests is different from other types of forest.

In the future, this type of index can be applied as a mechanism of health index assessment of mangrove areas in Peninsular Malaysia before pursuing development related activities. In fact, many studies previously conducted were based on soil, climatology, impact of erosion on mangrove trees, pests and disease, fire, etc., which can be employed for integration with our index, after mutual agreement created (if necessary). The study has presented NDVI as a potential health indicator once combined with the TC index for the mangrove area of the Tanjung Piai. 
Razali Sh. M., Nuruddin A. A., Lion M.: Mangrove Vegetation Health Assessment Based on Remote Sensing Indices for Tanjung Piai, Malay Peninsular

\section{CONCLUSIONS}

The study showed mangrove health assessment can be delineated and presented for assisting conservation interpretation based on satellite image which can be implemented for conservation activity for Peninsula Malaysia coastal areas. The study also suggests that unhealthy and healthy delineated areas should be preserved for maintaining mangrove areas from development-related activities, particularly infrastructure development.

The study found high NDVI value is an indication of high vegetation water content to high vegetation fractional vegetation cover (FVC). This is due to NDVI being correlated to biomass, leaf area index (LAI), and among them, also to productivity (Sánchez-Azofeifa et al., 2003). In the beginning, of mangrove species stays in a gap and as it grows to a certain height, they are started to build a mangrove community. However, in Johor, particularly Tanjung Piai coastal erosion is also responsible for the loss of mangrove cover due to long-term projects within other unfinished projects, namely those cited in a report by (Serina, 2017): the Tanjung Piai Maritime Industrial Park by Benelac Holdings Berhad, the Tanjung Agas Oil and Gas Maritime Industrial Park within the Pulai River, the Port of Tanjung Pelepas planned expansion, Singapore's mega-port development in Tuas, the Sunway Iskandar project around the Pendas River, and the impact on the sea grass meadows and coastal mangroves in the Tebrau Straits.

The high NDVI at site P5 (0.67) is due to far distance from risk wave's zone, therefore having young and growing trees with large lush green cover. Therefore, the area reflected greater NDVI indicated healthy vegetation that was found similar with a study conducted at Kelantan Delta in 2011 (Satyanarayana et al., 2011). The risk zone is the area where elevation is lower than the mean high tide level (Motamedi et al., 2014). Oppositely, as stated higher NDVI distributed to the eastern area appears away from the sea which this pattern is characterized by the sea, influenced by the wind, waves, and pollution.

\section{ACKNOWLEDGMENTS}

This study was granted by the Ministry of Water, Land and Natural Resources and supported by the Forest Research Institute of Malaysia (FRIM), under the RMK 11 research grant. The research was conducted from end of 2015 until end of 2017. The grant was specifically focused on research and programmes for enhancing planting methods, types of species, and other factors that affects mangroves in the coastal area of Peninsular Malaysia. A special thanks also to Johor Parks "Perbadanan Taman Negara (Johor)" for their assistance during data collection and plot establishment.

\section{REFERENCES}

Barau, A. S. (2017). Tension in the periphery: An analysis of spatial, public and corporate views on landscape change in Iskandar Malaysia, Landsc. Urban Plan., vol. 165, pp. 256266.

Crist, E. P. \& R. C. Cicone (1984). A Physically-Based Transformation of Thematic Mapper Data---The TM Tasseled Cap, IEEE Trans. Geosci. Remote Sens., vol. GE-22, no. 3, pp. 256263.

De Sherbinin, A., D., Carr S. Cassels, and L. Jiang (2007). Population and environment, Annu Rev Env. Resour., vol. 32, pp. 345-373. 
Drigo, R., Lasserre, B. and M. Marchetti (2009). Patterns and trends in tropical forest cover," Plant Biosyst. - An Int. J. Deal. with all Asp. Plant Biol., vol. 143, no. 2, pp. 311-327, Jul.

Gobron, N., Pinty, B., Verstraete, M. M. and J. Widlowski (2000). Advanced Vegetation Indices Optimized for Applications, Contract, vol. 38, no. 6, pp. 2489-2505.

Heenkenda, M. K., Joyce, K. E., Maier, S. W. and S. De Bruin (2015). ISPRS Journal of Photogrammetry and Remote Sensing Quantifying mangrove chlorophyll from high spatial resolution imagery, ISPRS J. Photogramm. Remote Sens., vol. 108, pp. 234-244.

Heenkenda, M., Maier, S. and K. Joyce (2016). Estimating Mangrove Biophysical Variables Using WorldView-2 Satellite Data: Rapid Creek, Northern Territory, Australia, J. Imaging, vol. 2 , no. 3, p. 24.

Hmimina, G., Dufrêne, E., Pontailler, J.-Y., Delpierre, N., Aubinet, M., Caquet, B., de Grandcourt, A., Burban, B., Flechard, C., Granier, A., Gross, P., Heinesch, B., Longdoz, B., Moureaux, C., Ourcival, J.-M., Rambal, S., Saint André, L. and K. Soudani (2013). Evaluation of the potential of MODIS satellite data to predict vegetation phenology in different biomes: An investigation using ground-based NDVI measurements, Remote Sens. Environ., vol. 132, pp. 145-158, May.

Hossain, M. D. \& A. A. Nuruddin (2016). Soil and Mangrove: A Review, J. Environ. Sci. Technol., vol. 9, no. 2, pp. 198-207, Feb.

Huang, C., Wylie, B., Yang, L., Homer, C. and G. Zylstra (2002). Derivation of a tasselled cap transformation based on Landsat 7 at-satellite reflectance, Int. J. Remote Sens., vol. 23, no. 8, pp. 1741-1748.

Jon Davies, N. Y., Mathhew U., Aikanathan, S., Chong, Ch. and G. Chong (2010). A Quick Scan of Peatlands in Malaysia, no. March, p. 86.

Juliana, W. A., Wan, M., Razali, S. and A. Latiff (2014). Mangrove Ecosystems of Asia, Mangrove Ecosyst. Asia, pp. 199-211.

Kamal, M., Phinn, S., Johansen, K. and N. S. Adi (2016). Estimation of mangrove leaf area index from ALOS AVNIR-2 data (A comparison of tropical and sub-tropical mangroves), AIP Conf. Proc., vol. 1755.

Kanniah, K. D., Sheikhi, A., Cracknell, A. P., Goh, H. C., Tan, K. P., Ho, C. S. and F. N. Rasli (2015). Satellite images for monitoring mangrove cover changes in a fast growing economic region in southern Peninsular Malaysia, Remote Sens., vol. 7, no. 11, pp. 1436014385 .

Kauth, R. J. \& G. S. Thomas (1976). The tasseled cap-A graphic de-scription of the spectral-temporal development of agricultural crops as seen by Landsat, in The Symposium on Machine Processing of Remotely Sensed Data, p. 4B-41-4B-50.

Kongwongjan, J., Suwanprasit, C. and P. Thongchumnum (2012). Comparison of vegetation indices for mangrove mapping using THEOS data, Proc. Asia-Pacific Adv. Netw., vol. 33, no. Mlc, pp. 56-64.

Kovacs, J. M., Wang, J. and F. Flores-Verdugo (2005). Mapping mangrove leaf area index at the species level using IKONOS and LAI-2000 sensors for the Agua Brava Lagoon, Mexican Pacific, Estuar. Coast. Shelf Sci., vol. 62, no. 1-2, pp. 377-384.

Lewis, R. R., Milbrandt, E. C., Brown, B., Krauss, K. W., Rovai, A. S., Beever, J. W. and L. L. Flynn (2015). Stress in mangrove forests: Early detection and preemptive rehabilitation are essential for future successful worldwide mangrove forest management, Mar. Pollut. Bull. 
Razali Sh. M., Nuruddin A. A., Lion M.: Mangrove Vegetation Health Assessment Based on Remote Sensing Indices for Tanjung Piai, Malay Peninsular

Luo, Z., Sun, O. J., Wang, E., Ren, H. and H. Xu (2010). Modeling Productivity in Mangrove Forests as Impacted by Effective Soil Water Availability and Its Sensitivity to Climate Change Using Biome-BGC, Ecosystems, vol. 13, no. 7, pp. 949-965, Aug.

Motamedi, S., Hashim, R., Zakaria, R., Song, K. Il and B. Sofawi (2014). Long-term assessment of an innovative mangrove rehabilitation project: Case study on Carey Island, Malaysia, Sci. World J., vol. 2014.

RAMSAR, (2003). Malaysia names three new Ramsar sites in Johor State. Retrieved September 8, 2003, from https://www.ramsar.org/news/malaysia-names-three-new-ramsar -sites-in-johor-state.

Rouse, J. W., Haas, R. H., Schell, J. A. and D. W. Deering (1974). Monitoring vegetation systems in the Great Plains with ERTS, in Proceedings of the Third Earth Resource Technology Satellite-1 Symposium (pp. 3010-3017).

Sánchez-Azofeifa, G. A., Castro, K. L., Rivard, B., Kalascka, M. R. and R. C. Harriss (2003). Remote Sensing Research Priorities in Tropical Dry Forest Environments1, Biotropica, vol. 35, no. 2, p. 134.

Satyanarayana, B., Mohamad, K. A., Idris, I. F., Husain, M. L. and F. Dahdouh-Guebas (2011). Assessment of mangrove vegetation based on remote sensing and ground-truth measurements at Tumpat, Kelantan Delta, East Coast of Peninsular Malaysia, Int. J. Remote Sens., vol. 32, no. 6, pp. 1635-1650.

Serina, R. (2017). Trends in Southeast Asia: Johor's Forest City faces critical challenges, no. 3. Singapore: ISEAS Publishing.

Shah, K., Mustafa Kamal, A. H., Rosli, Z., Hakeem, K. R. and M. M. Hoque (2016). Composition and diversity of plants in Sibuti mangrove forest, Sarawak, Malaysia, Forest Sci. Technol., vol. 12, no. 2, pp. 70-76.

Slik, J. W. F. \& K. a O. Eichhorn (2003). Fire survival of lowland tropical rain forest trees in relation to stem diameter and topographic position., Oecologia, vol. 137, no. 3, pp. 446-55, Nov.

Smith, A. M. S, Kolden, C. a., Tinkham, W. T., Talhelm, A. F., Marshall, J. D., Hudak, A. T., Boschetti, L., Falkowski, M. J., Greenberg, J. a., Anderson, J. W., Kliskey, A., Alessa, L., Keefe, R. F. and J. R. Gosz (2014). Remote sensing the vulnerability of vegetation in natural terrestrial ecosystems, Remote Sens. Environ., vol. 154, pp. 322-337, Jun.

Yang, X., Wang, F., Bento, C. P. M., Meng, L., van Dam, R., Mol, H., Liu, G., Ritsema, C. J. and V. Geissen (2015). Decay characteristics and erosion-related transport of glyphosate in Chinese loess soil under field conditions, Sci. Total Environ., vol. 530-531, pp. 87-95.

Yarbrough, L. D., Navulur, K. and R. Ravi (2014). Presentation of the Kauth-Thomas transform for WorldView-2 reflectance data, Remote Sens. Lett., vol. 5, no. 2, pp. 131-138.

Zhang, J. \& Y. Zhang (2007). Remote sensing research issues of the National Land Use Change Program of China, ISPRS J. Photogramm. Remote Sens., vol. 62, no. 6, pp. 461-472, Dec.

Zhang, Q., Xiao, X., Braswell, B., Linder, E., Baret, F. and B. Mooreiii (2005). Estimating light absorption by chlorophyll, leaf and canopy in a deciduous broadleaf forest using MODIS data and a radiative transfer model, Remote Sens. Environ., vol. 99, no. 3, pp. 357371 , Nov. 